\title{
Inequality in
}

\section{Central America}

\section{in the 1990s}

\author{
Juan Diego Trejos and Thomas H. Gindling
}

Juan Diego Trejos

Professor, University of Costa Rica

and researcher of the

Economic Science

Research Institute,

University of Costa Rica

• jdtrejos@cariari.ucr.ac.cr

Thomas H. Gindling

Professor, University of Maryland,

Baltimore County,

and visiting researcher of the

Economic Science

Research Institute,

University of Costa Rica

• tgindlin@umbc.edu

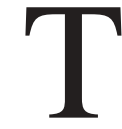

his study seeks to answer two questions: how and why has the distribution of labour income changed in Central America? and why does Costa Rica display greater equity? In order to answer these questions, a technique based on the estimation of earnings equations is used. The direction of the changes in inequality is not uniform and depends on the indicator used. Although only Costa Rica and Guatemala show an unambiguous deterioration in the 1990s, there are some phenomena common to all the labour markets studied that have contributed to increasing inequality. The most important of these is the increased dispersion of the number of hours worked, caused by increasing proportions of part-time and overtime workers in all countries. There are two main reasons for the lower relative inequality in Costa Rica: education is distributed more equally, and wage differences between rural and urban areas are smaller. These results suggest that public policies that universalize primary education and provide economic and social infrastructure to rural communities contribute to reducing inequality. 


\section{I}

\section{Introduction}

After the turbulent 1980s, which were marked by the debt crisis, political instability and armed conflicts, the Central American countries embarked on a set of economic reforms which accompanied and complemented the processes of pacification and restoration of democracy in several of them. These reforms were supported by the international financial organizations and the relevant agencies of the donor countries, especially the United States, and were in line with the so-called Washington Consensus, with different thrusts and degrees of intensity.

These reforms meant abandoning the style of development which had prevailed during the previous three decades and which was characterized by import substitution industrialization within the framework of a subregional common market, although there were big differences between the countries in terms of social and distributive policies and their initial situation in the process. This style of development was very successful in terms of growth in the 1960s, but it began to show signs of becoming unviable during the 1970s and collapsed with the debt crisis of the early 1980s. Costa Rica was the country which initiated the economic reforms first, in the mid-1980s, followed by Guatemala. The other Central American countries only began to make real progress in these efforts from the 1990s on.

The 1990s were marked by the resumption of economic growth in the subregion and the consolidation, albeit slow and incomplete, of a new outward-oriented style of development, the main driving force of which were exports to countries outside the subregion. The aim of the present study is to analyse the distributive changes which took place in that decade of economic reforms and pacification and to seek the reasons for the differences between countries and their evolution. In order to do this, special attention is paid to labour income, which is the main component in family income, and the causes of its distribution and evolution are studied. In conclusion, the main findings are recapitulated and their policy implications are identified.

\section{II}

\section{The context: a small but heterogeneous region}

Central America is small in size, population and economic capacity. As shown in table 1, it covers an area of $432,000 \mathrm{~km}^{2}$, which is equivalent to nearly a quarter of the area of Mexico and only a tenth of that of the United States. In the year 2000, its total population was approximately 33 million persons: almost $6 \%$ of the population of Latin America. Its total Gross Domestic Product (GDP) in that year was US\$ 50 billion at 1995 prices, equivalent to $3 \%$ of the Latin American GDP, $11 \%$ of the Mexican GDP, and less than $1 \%$ of that of the United States. Nicaragua is the largest country in the subregion, while Guatemala has the largest population and generates the largest total GDP. El Salvador is the smallest country, but the most densely populated, while Costa Rica has the smallest population. Half the population of Central America continues to live in rural areas, although in El Salvador and Nicaragua the urban population is beginning to register a slight majority.
The Central American subregion is also very heterogeneous. Using the most traditional indicator of relative economic development - the per capita GDP in 1995 dollars - in the year 2000 Costa Rica had twice the subregional average, with a level of over US\$ 3,600. El Salvador and Guatemala were close to the subregional average, with a per capita GDP close to US\$1,600 per year, while Honduras and Nicaragua had levels less than half the average, with a per capita GDP of less than US\$ 700. These differences are maintained, although they become less marked, when the purchasing power parity is used (UNDP, 2002), and as may be seen from figure 1, there have been no substantial changes in the last twenty years.

The heterogeneity in the subregion is also expressed in the relative levels of social development, which in turn is partly the result of social investment which likewise displays major disparities and reflects 
TABLE 1

Central America: Socio-economic indicators and their recent evolution, by countries

\begin{tabular}{|c|c|c|c|c|c|c|}
\hline Indicator & Costa Rica & El Salvador & Guatemala & Honduras & Nicaragua & Subregion \\
\hline Total population, 2000 (millions) & 4.0 & 6.3 & 11.4 & 6.5 & 5.1 & 33.2 \\
\hline Proportion of subregional total $(\%)$ & 12 & 19 & 34 & 20 & 15 & 100 \\
\hline Annual growth, 2000/1990 & 2.8 & 2.1 & 2.7 & 2.9 & 2.9 & 2.6 \\
\hline Percentage living in urban areas & 50 & 60 & 40 & 53 & 56 & 51 \\
\hline Total area (thousands of $\mathrm{km}^{2}$ ) & 50.9 & 20.9 & 108.9 & 112.1 & 139.0 & 431.8 \\
\hline Density (persons $/ \mathrm{km}^{2}$ ) & 79 & 300 & 105 & 58 & 37 & 77 \\
\hline GDP in year 2000 (millions of 1995 dollars) & 14774 & 10978 & 17695 & 4595 & 2446 & 50488 \\
\hline Proportion of subregional total (\%) & 29 & 22 & 35 & 9 & 5 & 100 \\
\hline Annual growth, 2000/1990 & 4.7 & 4.3 & 4.1 & 3.1 & 3.5 & 4.3 \\
\hline Per capita GDP in year 2000 (1995 dollars) & 3672 & 1749 & 1554 & 709 & 482 & 1519 \\
\hline Annual growth, 2000/1990 & 2.1 & 2.2 & 1.4 & 0.3 & 0.6 & 1.6 \\
\hline Social development in $2000^{\mathrm{a}}$ & 0.820 & 0.706 & 0.631 & 0.638 & 0.635 & 0.670 \\
\hline Position among 173 countries & 43 & 104 & 120 & 116 & 118 & 112 \\
\hline Trend 1990-2000 & Improved & Improved & Improved & Improved & Improved & Improved \\
\hline Per capita social expenditure, 1999 (1997 dollars) & 622 & 82 & 107 & 57 & 57 & 147 \\
\hline Fiscal priority (\% of public expenditure) & 43 & 27 & 46 & 34 & 37 & 38 \\
\hline Macroeconomic priority (\% of GDP) & 17 & 4 & 6 & 7 & 13 & 8 \\
\hline Trend 1990-1999 & Increased & Increased & Increased & Diminished & Increased & Increased \\
\hline \multicolumn{7}{|l|}{ Poverty around 1999} \\
\hline Poor persons (\% of total) & 20 & 50 & 61 & 80 & 70 & 59 \\
\hline Trend 1990-1999 & Diminished & Diminished & Diminished & Unchanged & Diminished & Diminished \\
\hline \multicolumn{7}{|l|}{ Total income inequality around 1999} \\
\hline Gini coefficient (persons - per capita income) & 0.47 & 0.52 & 0.58 & 0.56 & 0.58 & $\ldots$ \\
\hline \multicolumn{7}{|l|}{ Labour market around 1999} \\
\hline Net participation rate, men & 75 & 72 & 81 & 80 & 79 & 78 \\
\hline Trend 1990-1999 & Diminished & Diminished & Diminished & Increased & Increased & $\ldots$ \\
\hline Net participation rate, women & 36 & 42 & 42 & 41 & 39 & 40 \\
\hline
\end{tabular}

Source: Prepared by the authors on the basis of data from ECLAC (2001, 2002 and 2003), UNDP (2002) and Trejos (2002).

a As measured by the UNDP Human Development Index (HDI).

and increases the importance of the level of national income and the dissimilar distributive policies applied. Costa Rica has the highest per capita GDP, the highest level of social development, ${ }^{1}$ the least inequality and the lowest poverty count, all of which is based on a long-standing social development policy which has high macroeconomic and fiscal priority; as we will see below, this country shows the synergies that can be obtained by investing in human capital: higher

\footnotetext{
${ }^{1}$ As measured by the Human Development Index (HDI) of the United
} Nations Development Programme (UNDP). productivity, less inequality and less poverty. El Salvador occupies an intermediate position in terms of poverty, inequality and social development, while the other three countries are among the Latin American countries with the highest levels of poverty and inequality (ECLAC, 2002). ${ }^{2}$

\footnotetext{
2 The subregion is very vulnerable to natural disasters. These phenomena have hit the poorest countries hardest, as in the case of Hurricane Mitch in 1998. Several Central American countries have also suffered from serious armed conflicts, fostered by the big inequalities which existed, which further increased the gaps between them.
} 
FIGURE 1

Central America: Evolution of real per capita gross domestic product (Per capita GDP in 1995 dollars)

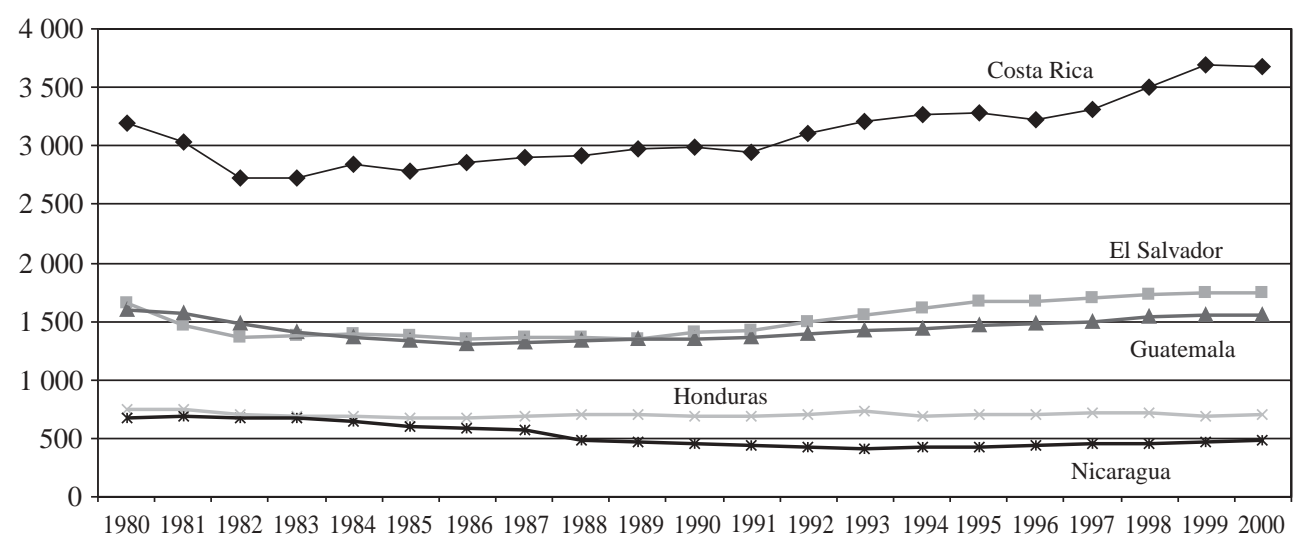

Source: ECLAC (2003).

The heterogeneity of the subregion is also observed in the labour market. Labour force participation rates are higher in the poorer countries, and have increased in all the countries because of the growing incorporation of women. Even so, except in El Salvador female participation continues to be only half that of men. The incidence of open unemployment ranges from $2 \%$ for Guatemala to $12 \%$ for Nicaragua. Only Costa Rica registered a slight increase in unemployment, which remained unchanged in the rest of the countries, except Nicaragua, where it went down to almost half of the high rate registered at the beginning of the decade. This diversity was also observed in the composition and characteristics of the employment generated. Costa Rica, and to a lesser extent El Salvador, had a more formalized labour market, with less weight of agricultural and lowproductivity activities (traditional agriculture and informal sector), a higher proportion of wage-earning jobs, and a somewhat better qualified labour force. In the subregion as a whole, however, one-third of employment continues to be linked with agricultural activities, half of the employed persons are in lowproductivity activities, $42 \%$ work as self-employed workers or unpaid family members, and half of all workers have not completed the first six grades of primary education.

After a generalized contraction in the per capita GDP in the 1980s, the subregion grew quite steadily in the 1990s at an average annual rate of $4.2 \%$ (1.6\% per capita), with increases in real social investment and improvements in the social development indicators (table 1 and figure 1). Even so, Guatemala, Honduras and Nicaragua have not yet managed to recover the level of GDP per capita already attained 20 years before; the countries which improved least in this respect were the same ones which were in the worst situation at the beginning of the 1990s, thus indicating a widening of internal gaps and heterogeneity.

Although all the countries of the subregion have undertaken economic reforms, there have been differences in the time when they applied them, their characteristics and their more general results. Costa Rica was the country which began economic reforms earliest (1985/1986), followed by Guatemala (1986/ 1987), Honduras (1990), Nicaragua (1993) and El Salvador (1993/1994). All initiated processes of greater trade openness, financial liberalization and fiscal reforms. Except for Costa Rica, all have progressed with major privatization programmes, but none have made significant reforms in labour legislation. ${ }^{3}$ The aim of the reforms applied has been to reorient production from the domestic or subregional market towards the rest of the world. Figure 2 shows that in the 1980s exports only increased significantly (as a percentage of GDP) in Costa Rica, which was the first country in the subregion to initiate reforms. In the 1990s, however, the importance of exports also began to increase in the other countries of the subregion, especially El Salvador and Nicaragua, in connection with maquila activities.

\footnotetext{
${ }^{3}$ For measures of the magnitude of the reforms in Latin America, see Lora (2001) and Morley, Machado and Pettinato (1999).
} 


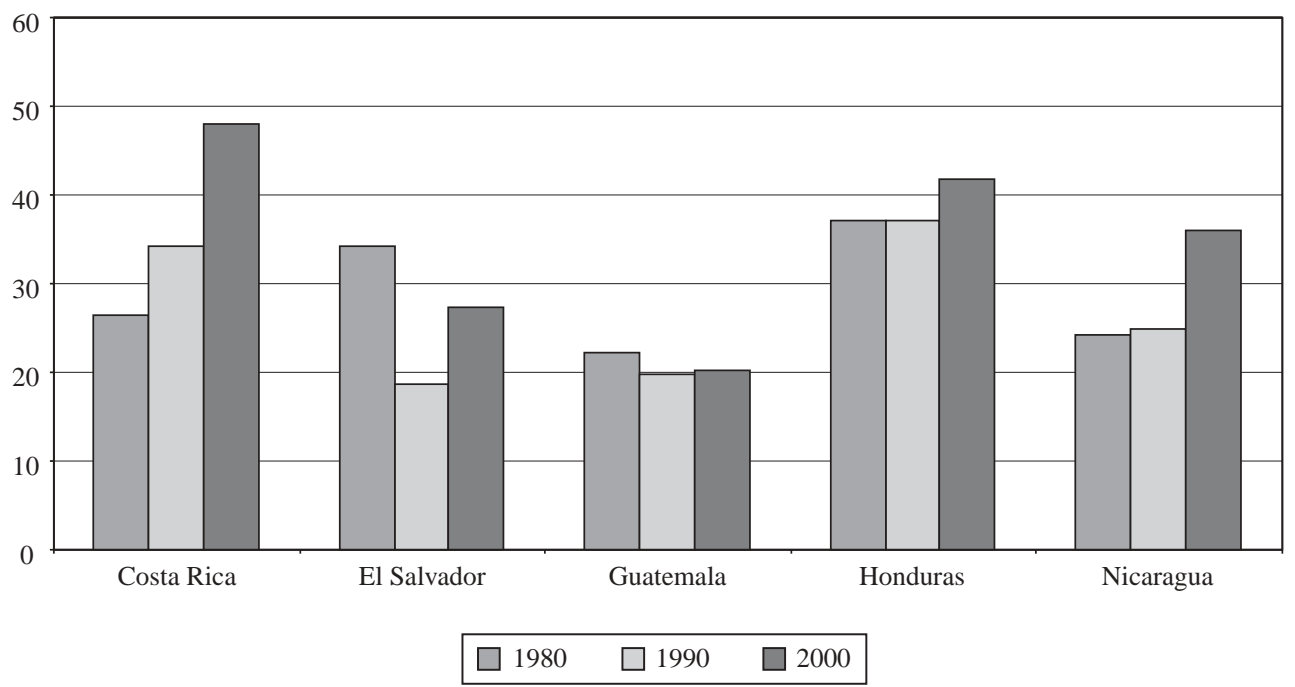

Source: ECLAC (2003).

\section{The sources of labour income inequality}

In order to study the causes of the differences in inequality between countries and over time, the distribution of labour income must be studied. ${ }^{4}$ This is done for three reasons: first, because whereas the household surveys used measure total family income with differences in coverage as regards the items measured in each country and year, labour income is measured in a more homogeneous manner in each country and year and is of better quality.

\footnotetext{
${ }^{4}$ In order to obtain the fullest possible picture of the evolution of labour income distribution in the 1990 s, we took into account the available estimates closest to the beginning and end of the decade for each country. The surveys used were: for Costa Rica, the Multipurpose Surveys for 1990 and 1999; for El Salvador, the Multipurpose Surveys for 1995 and 1999; for Guatemala, the National Socio-demographic Survey for 1989 and the Income and Expenditure Survey for 1998; for Honduras, the Permanent Multi-purpose Household Surveys for 1990 and 1999; and for Nicaragua, the National Household Surveys on Standards of Living for 1993 and 1998. These surveys were carried out in the months of July (Costa Rica), September (Honduras), February to June (Nicaragua 1993), April to September (Nicaragua, 1998), and the entire year (El Salvador and Guatemala).
}

Second, generally speaking, labour income contributes a very high proportion of total income and reflects a similarly high proportion of inequality (ECLAC, 2002). Székely and Hilgert (1999a), for example, calculate that labour income is responsible for a high proportion of total income inequality: $83 \%$ in Costa Rica (1997), 76\% in El Salvador (1995) and 73\% in Guatemala (1998). The inequality associated with labour income may also explain a high proportion of the changes in total income inequality. According to Székely and Hilgert (1999b), the changes associated with labour income can explain $100 \%$ or more of the changes in total income inequality in Costa Rica (19891997), El Salvador (1995-1998) and Honduras (19891998).

Finally, economic theory, and especially the progress made in econometric techniques, makes it possible to analyse more accurately the causes of changes in the distribution of labour income. Thus, in order to examine inequality in such income, use may be made of the theories on labour economics (such as the theory of human capital) and econometric techniques such as earnings equations. 


\section{Labour income inequality at the end of the 1990s}

In order to analyse labour income inequality, the population of the countries is placed on a uniform basis by considering only employed persons aged 15 or more who report their income and hours worked. This means excluding those under 15 in all countries, as well as unpaid family members, who form an important group in Guatemala, Honduras, Nicaragua and, to a lesser extent, El Salvador. Workers who do not report income are also excluded. This latter point is important in Costa Rica, especially in the case of self-employed workers, who are probably under-represented in this analysis. $^{5}$

Table 2 summarizes three indicators of relative inequality for employed persons aged 15 or more with known incomes, as well as sub-groups of these persons. The Gini coefficient is more sensitive to changes in the middle part of the distribution, while the Theil index provides information on changes in the upper part of the distribution and the variance of the income logarithm is more sensitive to what happens in the lower part of the distribution. Three groups of countries can be identified in the table. The first group corresponds to countries with low levels of inequality and includes Costa Rica. This country has the least unequal distribution, whatever the measure of inequality used or the sub-group of workers analysed. ${ }^{6}$ The second group corresponds to countries with moderate levels of inequality and includes El Salvador. El Salvador has a higher level of inequality than Costa Rica, but lower than the other countries of the subregion. The last group corresponds to countries with high levels of inequality, including Guatemala, Honduras and Nicaragua. Guatemala appears as the country with the highest level of inequality when the Gini coefficient or the variance of the income logarithm are used, while Nicaragua shows the highest level when the Theil index is used.

It should be noted that when labour income inequality is analysed, the results depend on those who

TABLE 2

Central America: Labour income inequality indicators, by countries, at the end of the 1990s

(For employed persons aged 15 or more with known income and hours worked)

\begin{tabular}{|c|c|c|c|c|c|}
\hline $\begin{array}{l}\text { Measure of inequality } \\
\text { and group of workers }\end{array}$ & $\begin{array}{c}\text { Costa Rica } \\
1999\end{array}$ & $\begin{array}{c}\text { El Salvador } \\
1999\end{array}$ & $\begin{array}{c}\text { Guatemala } \\
1998\end{array}$ & $\begin{array}{c}\text { Honduras } \\
1999\end{array}$ & $\begin{array}{c}\text { Nicaragua } \\
1998\end{array}$ \\
\hline \multicolumn{6}{|l|}{ All workers } \\
\hline Gini coefficient & 0.436 & 0.469 & 0.577 & 0.543 & 0.562 \\
\hline Theil index & 0.347 & 0.412 & 0.701 & 0.583 & 0.705 \\
\hline Variance of income logarithm & 0.775 & 0.779 & 1.436 & 1.203 & 1.039 \\
\hline \multicolumn{6}{|l|}{ Wage-earning workers ${ }^{\mathrm{a}}$} \\
\hline Gini coefficient & 0.406 & 0.433 & 0.502 & 0.465 & 0.494 \\
\hline Theil index & 0.306 & 0.338 & 0.502 & 0.427 & 0.528 \\
\hline Variance of income logarithm & 0.620 & 0.644 & 0.964 & 0.774 & 0.669 \\
\hline \multicolumn{6}{|c|}{ Wage-earning workers ${ }^{\mathrm{a}}$, except domestic service } \\
\hline Gini coefficient & 0.388 & 0.419 & 0.499 & 0.450 & 0.486 \\
\hline Theil index & 0.282 & 0.318 & 0.499 & 0.403 & 0.506 \\
\hline Variance of income logarithm & 0.529 & 0.599 & 0.927 & 0.705 & 0.643 \\
\hline \multicolumn{6}{|l|}{ Urban area workers } \\
\hline Gini coefficient & 0.435 & 0.461 & 0.560 & 0.495 & 0.546 \\
\hline Theil index & 0.337 & 0.402 & 0.630 & 0.484 & 0.647 \\
\hline Variance of income logarithm & 0.774 & 0.777 & 1.308 & 0.926 & 0.949 \\
\hline
\end{tabular}

Source: Calculated by the authors on the basis of household surveys of the respective countries and years.

a Excludes self-employed workers.

\footnotetext{
5 As failure to report income and unpaid family labour are concentrated in agricultural activities and rural areas, these fields are probably also under-represented.
} ${ }^{6}$ These sub-groups are shown in order to see whether the different
proportions of wage-earners and the different weights of rural areas
in the countries studied may be influencing the results. 
are working. In other words, they depend on the unemployment rate and the persons' decision whether or not to participate in the labour force. As already noted, in most countries there were no significant increases in unemployment in the period studied, and only Nicaragua registers a significant decline in unemployment that may be associated with the evolution of inequality considered below. Male participation rates did not register significant changes in that period, but female participation increased in all the countries. As we shall see below, this helps to explain the increase in the dispersion of hours worked and its impact on the increase in inequality.

\section{The sources of inequality: Fields' decomposition}

In order to examine the sources of labour income inequality, we used the techniques developed by Fields ${ }^{7}$ and extended by Yun (2002), which makes it possible to decompose monthly earnings inequality into components attributable to changes associated with the personal and job characteristics of the worker. This decomposition technique is based on the estimation of traditional semi-logarithmic earnings equations:

$$
\ln Y_{i t}=\Sigma_{j} B_{t j} * X_{i t j}+E_{i t}=\Sigma_{j} B_{t j} * Z_{i t j}
$$

where $\ln Y_{i t}$ is the logarithm of monthly labour income and $X_{i t j}$ are the variables $j$ associated with person $i$ in year $t$ which can affect earnings. The coefficients $B_{t j}$ measure the "prices" or wage premiums for each variable $X$. Thus, for example, the coefficient of years of schooling measures the increased wage that an employer must pay for a worker with one more year's schooling. The residual $E_{i t}$ is the part of the variation in earnings between workers which cannot be explained by the variation between the variables included in the equation.

The derivation of Fields' decomposition can be illustrated by using the variance of the logarithm of income as a measure of dispersion. In the light of the earnings equation, the variance of the logarithm of earnings can be written as follows:

$$
\begin{gathered}
\operatorname{Var}\left(\ln Y_{i t}\right)=\operatorname{Cov}\left(\ln Y_{i t}, \ln Y_{i t}\right)= \\
\operatorname{Cov}\left(\Sigma_{j} B_{t j} * Z_{i t}, \ln Y_{i t}\right)= \\
\Sigma_{j} \operatorname{Cov}\left(B_{t j} * Z_{i t j}, \ln Y_{i t}\right)
\end{gathered}
$$

\footnotetext{
${ }^{7}$ See Fields (2003) and Fields and Gyeongjoon (2000).
}

Dividing equation [2] by the variance of the logarithm of earnings, we have:

$$
\frac{1=\Sigma_{j} \operatorname{Cov}\left(B_{t j} * Z_{i t j}, \ln Y_{i t}\right)}{\operatorname{Var}\left(\ln Y_{i t}\right)}=\Sigma_{j} S_{j t}
$$

The $S_{j t}$ measure the proportion of the variance of the logarithm of income which is explained by each variable $j$ in country or year $t$. Shorrocks (1982) has shown that if income (or the logarithm of income) can be described as the sum of different components, then the $S_{j t}$ measure the contribution of each variable $j$ to inequality for a wide range of measures of inequality (not only variance), including the Gini coefficient and the Theil index. ${ }^{8}$

Although the $S_{j t}$ can be used to measure the contribution of each variable $j$ to the level of inequality, in order to measure the impact of each variable on the differences in inequality between countries or over time it is necessary to use something more than the $S_{j t}$. This is because the magnitude of the differences in inequality between countries or over time (and sometimes even the direction of change) will depend on the measure of inequality used. Thus, in order to measure the contribution of each variable to the change in inequality, it is necessary to multiply the $S_{j t}$ in each period or country $t$ by the corresponding measure of inequality. Specifically, if $I(t)$ is the measure of inequality iu period or country $t$, the change in inequality between periods or countries 1 and 2 can be written as follows:

$$
I(2)-I(1)=\Sigma_{j}\left\{I(2) * S_{j 2}-I(1) * S_{j 1}\right\}
$$

Equation [4] can be used to measure the contribution of each variable to the change in inequality between periods or countries.

The variables used to represent the characteristics of the labour market are: the logarithm of hours worked, and a set of binary variables representing the contribution or wage premium of working in the public sector (institutional sector), in formal or large enterprises (size of establishment) and in the different branches of industry (industry), where the mines and quarries branch is the control variable. ${ }^{9}$ The

\footnotetext{
8 The decomposition only works is the variables are fully linearizable. This excludes the possibility of interactions among the variables on the right hand side of the equation.

${ }^{9}$ As the countries use different classifications of industrial branches, the information has been homogenized to correspond to the nine main divisions of the International Standard Industrial Classification of all economic activities (ISIC, rev. 2).
} 
Central America: Fields' decomposition of labour income inequality, by countries, at the end of the 1990s

(For employed persons aged 15 or more with known income and hours worked)

\begin{tabular}{lcccc}
\hline $\begin{array}{l}\text { Measure of inequality } \\
\text { and group of workers }\end{array}$ & Costa Rica & El Salvador & Guatemala & Honduras \\
1999 & 1999 & 1999 & 1998 & 1998
\end{tabular}

Proportion of inequality explained

by each characteristic $\left(S_{j}\right)$

\begin{tabular}{|c|c|c|c|c|c|}
\hline All characteristics & 1.00 & 1.00 & 1.00 & 1.00 & 1.00 \\
\hline Education (years) & 0.19 & 0.25 & 0.19 & 0.21 & 0.18 \\
\hline $\operatorname{Sex}(\operatorname{men}=1)$ & 0.03 & 0.02 & 0.05 & 0.03 & 0.01 \\
\hline Zone $($ urban $=1)$ & 0.01 & 0.03 & 0.03 & 0.05 & 0.02 \\
\hline Hours worked (log) & 0.18 & 0.06 & 0.11 & 0.06 & 0.01 \\
\hline Institutional sector $($ public $=1)$ & 0.02 & 0.05 & 0.00 & 0.01 & -0.01 \\
\hline Size of establishment $(6$ or more $=1)$ & 0.06 & 0.06 & 0.03 & 0.07 & 0.03 \\
\hline Experience (age-education-6) & 0.00 & 0.00 & 0.00 & -0.01 & 0.00 \\
\hline Industry (set of binary variables) & 0.02 & 0.03 & 0.02 & 0.03 & 0.08 \\
\hline Residual & 0.50 & 0.51 & 0.56 & 0.55 & 0.68 \\
\hline
\end{tabular}

Source: Prepared by the authors on the basis of household surveys of the respective countries and years.

characteristics of persons include variables associated with human capital, such as years of formal education and years of potential experience, as well as two binary variables which reflect the wage premium received by men over women (sex) and residence in urban areas (zone). ${ }^{10}$

Table 3 shows the $S_{j t}$ [equation 3], or the proportion of earnings inequality that can be explained by each variable associated with labour market and personal characteristics in each country. ${ }^{11}$ The results show that in all the countries education is the main source of measured inequality, since it explains between $18 \%$ and $25 \%$ of total inequality. The differences in hours worked between different workers make dissimilar contributions in the different countries, although in general they tend to occupy second place as an explanatory factor. Costa Rica is the country where these differences have the greatest weight (18\%), followed by Guatemala, where they are responsible for
$11 \%$ of total inequality, about half the level of Costa Rica; in Honduras (6\%), El Salvador (6\%) and in Nicaragua they play only a marginal role $(1 \%)$.

The differences between large (formal) and small (informal) enterprises are responsible for between 7\% and $6 \%$ of total inequality in Honduras, Costa Rica and El Salvador. The differences between industries explain $8 \%$ of such inequality in Honduras. Individually, no other characteristic manages to explain even $5 \%$ of total inequality in any of the countries. This means that the inequality associated with all measured characteristics explains a maximum of $50 \%$ of total inequality (Costa Rica) and a minimum of $32 \%$ (Nicaragua), with the remainder being due to the residual of the earnings equation. The proportion of inequality due to this residual is the result of inequality between persons with the same education, sex, area of residence, hours worked, institutional sector, size of establishment, experience and industrial branch.
10 The decomposition assumes a linear relation between years of education and logarithm of income. As Contreras (2003) notes, in Chile, as well as other countries, there is evidence that this relation may not be so. In order to take account of the possibility that the relation may not be linear, equations and decompositions were estimated using four binary variables for education (full primary, incomplete secondary, full secondary and higher education). The results obtained with this specification are very similar to the results presented in the body of this paper and do not alter the conclusions on the influence of educational distribution and performance on the degree and evolution of inequality and on the differences between countries. The linear specification originally proposed has therefore been maintained, and the basic results are presented in appendix A. ${ }^{11}$ For the earnings equations, see appendix A. 


\section{IV}

\section{The sources of changes in inequality in the 1990s}

Analysis of the changes in inequality during the 1990s is a difficult matter, because household surveys became a generalized practice only at the end of that period. In the present section, the survey closest to the beginning of the 1990s available in each country is used in order to gain an idea of the evolution of inequality during the decade. Thus, the surveys used were the 1989 survey for Guatemala, that of 1990 for Costa Rica and Honduras, that of 1993 for Nicaragua and that of 1995 for El Salvador. The data on the early years of the decade likewise correspond to years close to the beginning of the structural adjustment programmes.

\section{Changes in inequality of labour income distribution}

Table 4 shows the inequality indicators for each Central American country, using data for the early years of the 1990s, and compares them with the indicators for the end of the decade already analysed in previous sections.

The data in table 4 indicate that inequality in the distribution of labour income unambiguously increased only in Costa Rica and Guatemala, since only in these countries did all three indicators of inequality increase. In this group, Guatemala displayed the biggest increase in inequality. In Nicaragua and Honduras inequality either increased or decreased, depending on the indicator used (figure 3). In Honduras, the variance of the logarithm of income increased, while the Gini coefficient and Theil index went down. ${ }^{12}$ The variance

\begin{abstract}
${ }^{12}$ This result is not due to the existence outliers in the data, because in Honduras the figures remained unchanged even when the poores $1 \%$ of the distribution were eliminated in each year. It should be noted that the samples amounted to more than $1 \%$ of the population in Costa Rica and El Salvador, but were smaller for the other countries (Székely and Hilgert, 1999a). In the view of those authors, the smaller samples in Honduras, Guatemala and Nicaragua are reflected in greater statistical errors.
\end{abstract}

TABLE 4

Central America: Evolution of labour income inequality, by countries, in the 1990s

(For employed persons aged 15 or more and reporting income, ordered by their labour income)

\begin{tabular}{|c|c|c|c|c|c|}
\hline Indicator & Costa Rica & El Salvador & Guatemala & Honduras & Nicaragua \\
\hline \multicolumn{6}{|l|}{ Year of survey } \\
\hline Around 1990 & 1990 & 1995 & 1989 & 1990 & 1993 \\
\hline Around 1999 & 1999 & 1999 & 1998 & 1999 & 1998 \\
\hline \multicolumn{6}{|l|}{ Gini coefficient } \\
\hline Around 1990 & 0.410 & 0.462 & 0.517 & 0.562 & 0.542 \\
\hline Variation & 0.026 & 0.007 & 0.060 & -0.019 & 0.021 \\
\hline \multicolumn{6}{|l|}{ Theil index } \\
\hline Around 1990 & 0.319 & 0.447 & 0.563 & 0.759 & 0.560 \\
\hline Around 1999 & 0.347 & 0.412 & 0.701 & 0.583 & 0.705 \\
\hline Variation & 0.027 & -0.035 & 0.139 & -0.176 & 0.145 \\
\hline Around 1990 & 0.703 & 0.686 & 1.025 & 1.029 & 1.171 \\
\hline Around 1999 & 0.775 & 0.779 & 1.436 & 1.203 & 1.039 \\
\hline Variation & 0.072 & 0.093 & 0.411 & 0.174 & -0.132 \\
\hline
\end{tabular}

Source: Prepared by the authors on the basis of household surveys of the respective countries and years. 
FIGURE 3

Central America: Variation in labour income inequality indicators in the 1990s

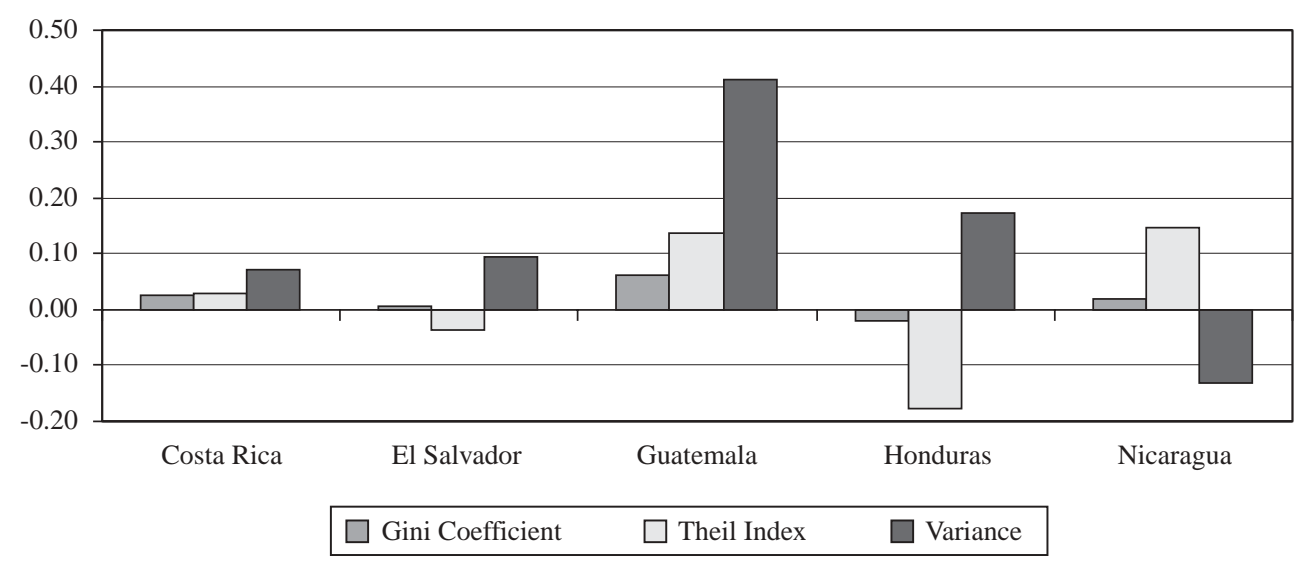

Source: Table 4.

in the logarithm of labour income, which is more sensitive to changes in the lower part of the distribution, went down in Nicaragua, while there were increases in the Gini coefficient, which is more sensitive to changes in the middle part of the distribution, and the Theil index, which is more sensitive to changes in the upper part of the distribution. This suggests that the labour income of workers at the bottom of the distribution increased more or went down less than that of workers in the middle of the distribution, while the earnings of the middle group did not increase faster than those of workers in the upper part of the distribution. The marked reduction in unemployment, associated with greater employment opportunities for less skilled workers, may be the reason for this evolution. Another possibility is that there is a problem with the data for Nicaragua; especially, that there are outliers in the data at the lower part of the distribution which may be responsible for the decline in the variance of the logarithm of income. In order to test this possibility, the poorest $1 \%$ were eliminated and the change in the variance of the logarithm was re-estimated. When this was done, the variance of the logarithm of labour income in Nicaragua increased between 1993 and 1998, which suggests that the decline observed in the variance of the logarithm of income may indeed be due to problems with the data.

The evolution thus described does not alter the order of the countries in the three inequality groups mentioned. Costa Rica remains the country with the lowest inequality and El Salvador stays in the intermediate group. Guatemala, Honduras and Nicaragua continue to be the countries with the highest levels of inequality in the 1990s, although their order within that group varies according to the year and the indicator used. When the Gini coefficient is used, Honduras was the most unequal country around 1990, while Guatemala was the most unequal at the end of the decade. Using the Theil index, Honduras was the most unequal in 1990, while Nicaragua was the most unequal at the end of the decade. Finally, using the variance of the logarithm of income, Nicaragua was the most unequal around 1990, while that position was occupied by Guatemala at the end of the decade.

In short, the data do not display a uniform pattern of evolution of labour income distribution in the 1990s; that pattern depends on the indicator used. Only Costa Rica and Guatemala show a clear deterioration of income inequality. Beneath these overall changes there are features which are common to the labour markets of all the countries, however. These phenomena can be identified by analysing the sources of the changes in labour income inequality.

\section{Sources of labour income inequality at the beginning of the 1990s}

Table 5 is a replica of table 3, using data for around 1990. At the beginning of the 1990s, education continued to be the variable which most influenced labour income inequality. Only in Costa Rica did the 
TABLE 5

Central America: Fields' decomposition of labour income inequality, by countries, at the beginning of the 1990s

(For employed persons aged 15 or more with known income and hours worked)

\begin{tabular}{lcccc}
\hline Variables & Costa Rica & El Salvador & Guatemala & Honduras \\
1989 & 1990 & 1995 & 1990 & 1993 \\
\hline
\end{tabular}

Proportion of inequality explained

by each characteristic $\left(\mathrm{S}_{\mathrm{j}}\right)$

\begin{tabular}{|c|c|c|c|c|c|}
\hline All characteristics & 1.00 & 1.00 & 1.00 & 1.00 & 1.00 \\
\hline Education (years) & 0.19 & 0.19 & 0.21 & 0.24 & 0.18 \\
\hline $\operatorname{Sex}(\operatorname{man}=1)$ & 0.02 & 0.03 & 0.01 & 0.04 & 0.00 \\
\hline Zone (urban = 1) & 0.01 & 0.05 & 0.03 & 0.04 & 0.06 \\
\hline Hours worked $(\log )$ & 0.13 & 0.06 & 0.03 & 0.04 & 0.02 \\
\hline Institutional sector (public = 1) & 0.04 & 0.03 & 0.02 & 0.02 & -0.01 \\
\hline Size of establishment $(6$ or more $=1)$ & 0.06 & 0.04 & 0.09 & 0.07 & 0.06 \\
\hline Experience (age-education-6) & 0.01 & 0.00 & -0.02 & -0.01 & -0.01 \\
\hline Industry (set of binary variables per branch) & 0.03 & 0.06 & 0.09 & 0.01 & 0.09 \\
\hline Residual & 0.52 & 0.54 & 0.56 & 0.55 & 0.61 \\
\hline
\end{tabular}

Source: Prepared by the authors on the basis of household surveys of the respective countries and years.

number of hours worked continue to be the second most important source of inequality; in Guatemala and Nicaragua the wage gaps between industries are more significant on the whole, while in Honduras the wage gap by size of enterprise was the most important. This latter variable is also important as a factor of inequality in the rest of the countries of the subregion, while the weight of the residual in each country, or the part of inequality not explained by the incorporated variables, was similar both at the beginning and the end of the decade.

As already noted, in order to measure the contribution of each variable to the overall change in inequality, the $S_{i j}$ for each period or country $t$ must be multiplied by the corresponding measure of inequality [equation 4]. Table 6 shows the contribution of each variable to the change in one of the measures of inequality: the variance of the logarithm of labour income. ${ }^{13}$ As shown in the table, in all the countries except Nicaragua three phenomena furthered the increase in labour income inequality in the 1990s: the changes related with education, hours worked and the residual. In Guatemala, the changes related with the worker's sex and experience also contribute to the increased inequality. In contrast, the changes related with size

\footnotetext{
${ }^{13}$ It should be recalled that when the variance of the logarithm of labour income is used as an indicator of inequality, this increases in all the countries except Nicaragua.
}

of enterprise and the industry in which the worker is employed promote a reduction in inequality in Guatemala and Nicaragua. The other variables have only a slight impact on changes in inequality.

\section{Yun's decomposition: distinguishing the effects of differences in "prices" and the distribution of personal characteristics}

Each variable can contribute to the differences in total inequality between countries or over time in two ways: because the "prices" (coefficients $B_{j}$ ) of those characteristics differ between countries or over time, or because the dispersion of those characteristics (changes in the dispersion of $Z_{j}$ ) differ between countries or over time. Thus, for example, table 6 shows that in the 1990s the changes related with education helped to accentuate inequality in most of the Central American countries. But this might have been because the price of education (the coefficient on the years of education variable) rose, or because inequality in the distribution of levels of education among workers increased. It would therefore be useful to be able to distinguish between changes in inequality caused by variations in the price coefficients and changes due to variations in the distribution of each $Z_{j}$. Yun (2002) derives an extension of Fields' decomposition for the variance of the logarithm of earnings which makes such separation possible. Following the logic of Juhn, Murphy and Pierce (1993), Yun (2002) constructed an "auxiliary" 
Central America: Contribution of each variable to changes in the variance of logarithm $\left(S_{j}^{*} \operatorname{VarLog} Y\right)$

(For employed persons aged 15 or more with known income and hours worked)

\begin{tabular}{|c|c|c|c|c|c|}
\hline Variables & $\begin{array}{c}\text { Costa Rica } \\
1990 / 1999\end{array}$ & $\begin{array}{c}\text { El Salvador } \\
1995 / 1999\end{array}$ & $\begin{array}{c}\text { Guatemala } \\
1989 / 1998\end{array}$ & $\begin{array}{l}\text { Honduras } \\
1990 / 1999\end{array}$ & $\begin{array}{l}\text { Nicaragua } \\
1993 / 1998\end{array}$ \\
\hline Change in the variance of the logarithm & 0.08 & 0.10 & 0.41 & 0.17 & -0.13 \\
\hline Education (years) & 0.02 & 0.06 & 0.07 & 0.01 & -0.02 \\
\hline Sex $($ men $=1)$ & 0.00 & -0.01 & 0.06 & 0.00 & 0.01 \\
\hline Zone $($ urban $=1)$ & 0.00 & -0.01 & 0.02 & 0.02 & -0.04 \\
\hline Hours worked (log) & 0.05 & 0.01 & 0.13 & 0.04 & -0.02 \\
\hline Institutional sector (public $=1$ ) & -0.01 & 0.02 & -0.01 & -0.01 & 0.00 \\
\hline Size of establishment $(6$ or more $=1)$ & 0.00 & 0.02 & -0.04 & 0.01 & -0.04 \\
\hline Experience (age-education-6) & 0.00 & 0.00 & 0.03 & -0.01 & 0.01 \\
\hline Industry (set of binary variables) & 0.00 & -0.02 & -0.06 & 0.02 & -0.03 \\
\hline Residual & 0.03 & 0.02 & 0.23 & 0.10 & -0.02 \\
\hline
\end{tabular}

Source: Calculated by the authors on the basis of household surveys of the respective countries and years.

distribution, using the $B$ s for period or country 2 and the $\mathrm{Zs}$ of period or country 1 :

$$
\ln Y_{i, a u x}=\Sigma_{j} B_{2 j} * X_{i l j}+E_{i l}=\Sigma_{j} B_{2 j} * Z_{i l j}
$$

The change in the variance of the earnings logarithm may be written as:

$$
\begin{aligned}
& \operatorname{Var}\left(\ln Y_{2}\right)-\operatorname{Var}\left(\ln Y_{1}\right)=\left[\operatorname{Var}\left(\ln Y_{\text {aux }}\right)-\operatorname{Var}\left(\ln Y_{1}\right)\right]+ \\
& {\left[\operatorname{Var}\left(\ln Y_{2}\right)-\operatorname{Var}\left(\ln Y_{\text {aux }}\right)\right]=\Sigma_{j}\left[S_{\text {jaux }} \operatorname{Var}\left(\ln Y_{\text {aux }}\right)-\right.} \\
& \left.S_{j 1 *} \operatorname{Var}\left(\ln Y_{1}\right)\right]+\left[S_{j 2 *} \operatorname{Var}\left(\ln Y_{2}\right)-\right. \\
& \left.S_{\text {jaux }} \text { Var }\left(\ln Y_{\text {aux }}\right)\right] \\
& =\Sigma_{j}\left[B_{2 j}{ }^{*} D E\left(Z_{i l j}\right) * \operatorname{Corr}\left(Z_{i l j,} \ln Y_{\text {aux }}\right) * D E\left(\ln Y_{\text {aux }}\right)-\right. \\
& \left.B_{l j}{ }^{*} D E\left(Z_{i l j}\right) * \operatorname{Corr}\left(Z_{i l j,}, \ln Y_{a l}\right) * D E\left(\ln Y_{a l}\right)\right]+ \\
& \Sigma_{j}\left[B_{2 j}{ }^{*} D E\left(Z_{i 2 j}\right) * \operatorname{Corr}\left(Z_{i 2 j,}, \ln Y_{2}\right) * D E\left(\ln Y_{2}\right)-\right. \\
& \left.B_{2 j}{ }^{*} \operatorname{DE}\left(Z_{i j j}\right) * \operatorname{Corr}\left(Z_{i l j,}, \ln Y_{a u x}\right) * D E\left(\ln Y_{\text {aux }}\right)\right]
\end{aligned}
$$

where the first line of equation [7] shows the contribution to the difference (between periods or countries) in the variance of the income logarithm by changes or differences in each of the coefficients, while the second line shows the contribution of the changes or differences in the variance of each $Z_{j}{ }^{14}$

\footnotetext{
${ }^{14}$ A possible problem of the earnings equations is selection bias, the traditional correction for which is Heckman's technique. The earnings equations have not been estimated with Heckman's correction, however, because it is not possible to integrate this technique with the decomposition proposed by Yun, which was used here.
}

Table 7 and figure 4 show Yun's decomposition of the changes in labour income inequality (measured with the variance of the logarithm of labour income) in each Central American country during the 1990s. ${ }^{15}$ A first result worthy of note is that in all the countries, except Nicaragua, an increase in the inequality of number of hours worked among workers (distribution effect) promotes an increase in inequality of earnings. The effect of the number of hours worked is greater in Guatemala and Costa Rica than in the other Central American countries.

The inequality in the number of hours worked increased because the proportion of workers with a full working day went down in each country, while the proportion of those with part-time and overtime employment increased ${ }^{16}$ (table 8). The decline in the proportion of workers with a full working day was partly due to the increase in the participation of women in the labour force, because women work part-time more frequently than men. The increase in inequality of hours worked was also partly due to the increase in the proportion of workers employed in small enterprises, who are more likely to work part-time or overtime. The inequality in hours worked was also accentuated by the fact that there was a decline in the

\footnotetext{
${ }^{15}$ For an application of these techniques to Costa Rica, with a longer time horizon, see Gindling and Trejos (2004).

${ }^{16}$ By "overtime" we mean a working day longer than the legal or normal day, which in Central America corresponds to a working week of up to 48 hours. Thus, "overtime" corresponds to a working week of 49 hours or more. Part-time workers are those who work less than 40 hours a week.
} 
TABLE 7

Central America: Yun's decomposition of the

differences in labour income inequality

(For employed persons aged 15 or more with known income and hours worked)

\begin{tabular}{|c|c|c|c|c|c|}
\hline Variables & $\begin{array}{c}\text { Costa Rica } \\
1990 / 1999\end{array}$ & $\begin{array}{c}\text { El Salvador } \\
1995 / 1999\end{array}$ & $\begin{array}{c}\text { Guatemala } \\
1989 / 1998\end{array}$ & $\begin{array}{l}\text { Honduras } \\
\text { 1990/1999 }\end{array}$ & $\begin{array}{l}\text { Nicaragua } \\
1993 / 1998\end{array}$ \\
\hline \multicolumn{6}{|c|}{ Contribution of changes in the coefficients (or "prices") of each variable } \\
\hline $\begin{array}{l}\text { Total price effect } \\
\text { Education (years) } \\
\text { Sex }(\text { men }=1) \\
\text { Zone (urban }=1) \\
\text { Hours worked }(\log ) \\
\text { Institutional sector (public }=1) \\
\text { Size of establishment }(6 \text { or more }=1 \text { ) } \\
\text { Experience (age-education-6) } \\
\text { Industry (set of binary variables) }\end{array}$ & $\begin{array}{r}-\mathbf{0 . 0 2} \\
0.00 \\
0.00 \\
0.00 \\
0.00 \\
0.00 \\
0.00 \\
-0.01 \\
-0.01\end{array}$ & $\begin{array}{r}\mathbf{0 . 0 4} \\
0.05 \\
-0.01 \\
-0.01 \\
0.00 \\
0.02 \\
0.01 \\
0.00 \\
-0.02\end{array}$ & $\begin{array}{r}\mathbf{0 . 0 7} \\
0.04 \\
0.05 \\
0.01 \\
0.04 \\
-0.01 \\
-0.04 \\
0.03 \\
-0.06\end{array}$ & $\begin{array}{r}\mathbf{0 . 0 4} \\
-0.02 \\
0.00 \\
0.02 \\
0.02 \\
-0.01 \\
0.01 \\
-0.01 \\
0.03\end{array}$ & $\begin{array}{r}-\mathbf{0 . 1 4} \\
-0.03 \\
0.02 \\
-0.04 \\
-0.01 \\
0.00 \\
-0.04 \\
0.01 \\
-0.04\end{array}$ \\
\hline \multicolumn{6}{|c|}{ Contribution of changes in the distribution of each variable } \\
\hline $\begin{array}{l}\text { Total distribution effect } \\
\text { Education (years) } \\
\text { Sex }(\text { men }=1) \\
\text { Zone (urban }=1) \\
\text { Hours worked }(\log ) \\
\text { Institutional sector (public }=1) \\
\text { Size of establishment }(6 \text { or more }=1 \text { ) } \\
\text { Experience (age-education-6) } \\
\text { Industry (set of binary variables) }\end{array}$ & $\begin{array}{l}\mathbf{0 . 0 7} \\
0.01 \\
0.01 \\
0.00 \\
0.05 \\
0.00 \\
0.00 \\
0.00 \\
0.00\end{array}$ & $\begin{array}{l}\mathbf{0 . 0 3} \\
0.01 \\
0.00 \\
0.00 \\
0.01 \\
0.00 \\
0.01 \\
0.00 \\
0.00\end{array}$ & $\begin{array}{r}\mathbf{0 . 1 1} \\
0.03 \\
0.02 \\
0.00 \\
0.08 \\
-0.01 \\
-0.01 \\
0.01 \\
-0.01\end{array}$ & $\begin{array}{l}\mathbf{0 . 0 6} \\
0.04 \\
0.00 \\
0.00 \\
0.02 \\
0.00 \\
0.00 \\
0.00 \\
0.00\end{array}$ & $\begin{array}{l}\mathbf{0 . 0 2} \\
0.01 \\
0.00 \\
0.00 \\
0.00 \\
0.00 \\
0.00 \\
0.01 \\
0.01\end{array}$ \\
\hline
\end{tabular}

Source: Calculated by the authors on the basis of household surveys of the respective countries and years.

FIGURE 4

Central America: Yun's decomposition of the

differences in labour income inequality

Contribution of changes in the distribution of each variable

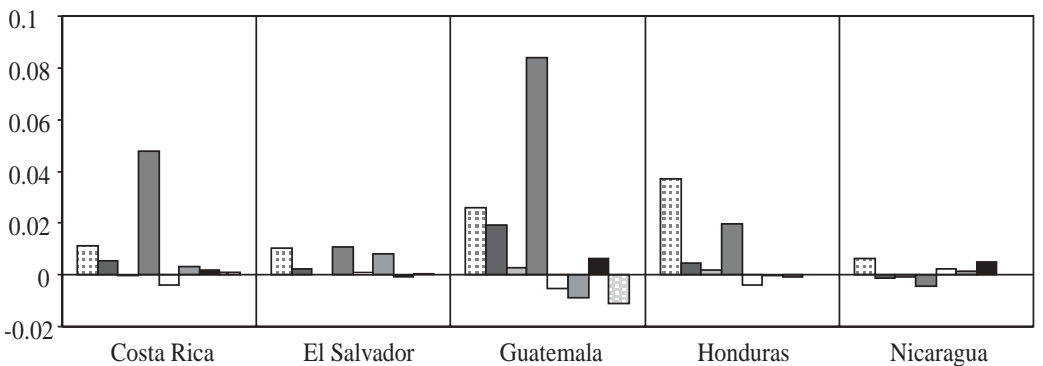

Contribution of changes in the coefficients of each variable

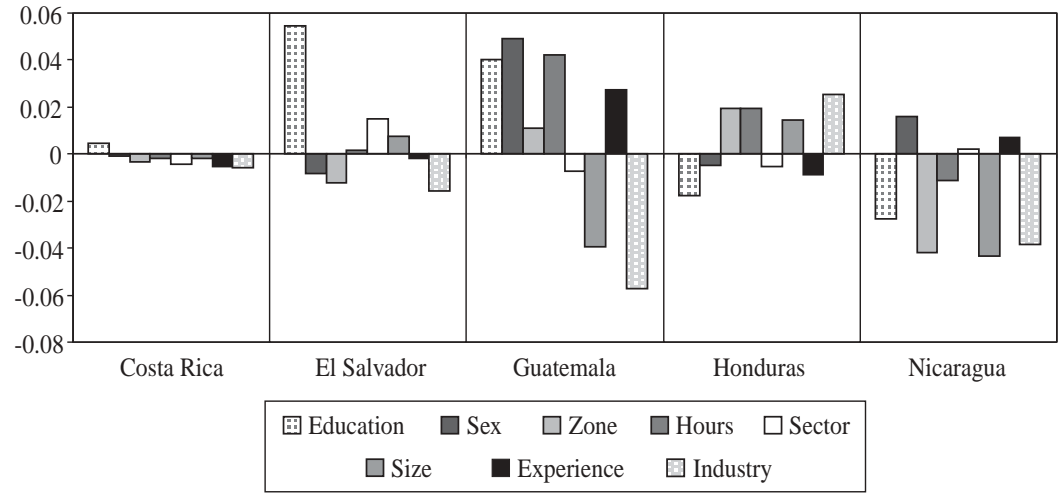

Source: Table 7. 
TABLE 8

Central America: Changes in the proportions of all workers, by sex, sector and type of working day

(For employed persons aged 15 or more with known income and hours worked)

\begin{tabular}{|c|c|c|c|c|c|}
\hline Change in the proportion of workers & $\begin{array}{c}\text { Costa Rica } \\
1990 / 1999\end{array}$ & $\begin{array}{c}\text { El Salvador } \\
1995 / 1999\end{array}$ & $\begin{array}{c}\text { Guatemala } \\
1989 / 1998\end{array}$ & $\begin{array}{c}\text { Honduras } \\
1990 / 1999\end{array}$ & $\begin{array}{l}\text { Nicaragua } \\
1993 / 1998\end{array}$ \\
\hline \multicolumn{6}{|l|}{ A. By type of working day } \\
\hline Part-time (39 hours or less) & 1.89 & 4.97 & 15.95 & 5.72 & 0.24 \\
\hline Full-time (40-48 hours) & -6.75 & -5.67 & -16.47 & -7.28 & -3.25 \\
\hline Overtime (49 hours or more) & 4.86 & 0.70 & 0.51 & 1.56 & 3.01 \\
\hline \multicolumn{6}{|l|}{ B. By sex } \\
\hline Men & -3.26 & -4.84 & -10.06 & -7.52 & 2.23 \\
\hline Women & 3.27 & 4.84 & 10.06 & 7.52 & -2.22 \\
\hline \multicolumn{6}{|l|}{ C. By sector } \\
\hline Small private firms & 5.46 & 3.40 & 4.20 & -0.32 & -0.17 \\
\hline Large private firms & -0.40 & -2.86 & -0.98 & 2.29 & 7.82 \\
\hline Public sector & -5.02 & -0.54 & -3.23 & -1.94 & -7.66 \\
\hline \multicolumn{6}{|l|}{ D. By sex and type of working day } \\
\hline Men, part-time & -0.58 & 2.78 & 5.65 & 1.71 & 0.44 \\
\hline Women, part-time & 2.48 & 2.18 & 10.30 & 4.01 & -0.20 \\
\hline Men, overtime & 3.29 & -2.24 & 0.01 & 0.08 & 3.56 \\
\hline Women, overtime & 1.57 & 2.94 & 0.50 & 1.49 & -0.54 \\
\hline \multicolumn{6}{|l|}{ E. By sector and type of working day } \\
\hline Small private firms, part-time & 2.48 & 3.90 & 13.80 & 4.74 & -1.95 \\
\hline Large private firms, part-time & 0.11 & 0.98 & 1.94 & 0.66 & 3.47 \\
\hline Public sector, part-time & -0.69 & 0.09 & 0.22 & 0.32 & -1.29 \\
\hline Small private firms, overtime & 3.71 & 0.99 & -1.83 & -1.42 & 1.77 \\
\hline Large private firms, overtime & 1.46 & -0.01 & 2.58 & 2.92 & 3.60 \\
\hline Public sector, overtime & -0.30 & -0.28 & -0.24 & 0.07 & -2.36 \\
\hline
\end{tabular}

Source: Calculated by the authors on the basis of household surveys of the respective countries and years.

proportion of workers in the public sector, where fulltime workers predominate. This decline was a result of the economic reforms adopted in the subregion. In addition, the changes in the number of hours worked in each sector, sex or industry also helped to increase the proportion of workers with part-time or overtime jobs.

The increase in overtime jobs was mainly among workers in the larger private firms. In most of the countries the proportion of workers with overtime went down in the public sector, and in some countries in small enterprises too. The greater proportion of workers with overtime in large private firms may be the result of the economic reforms, which made it necessary to improve the productivity of the workers and the competitiveness of those firms.

At the other extreme, the increase in part-time workers was mainly in small enterprises (the informal sector). In the two countries where inequality of hours worked increased most - Costa Rica and Guatemalathere was a considerable increase in the proportion of women who work in small enterprises. This increase in the proportion of women workers and in the informalization of the labour force in Central America is described in Trejos (2002). ${ }^{17}$

Other results are also worthy of note in this respect (table 7): in all the Central American countries inequality in the distribution of education among workers promoted greater inequality in the distribution

\footnotetext{
17 The increase in the proportion of part-time workers took place mainly in the industries producing non-tradeable goods. In all the countries, the industrial branches registering the biggest increases in part-time workers were commerce, construction and services. Only in Nicaragua was there an increase in the proportion of such workers in industries producing tradeable goods: manufacturing and agriculture. This latter feature means that the increase in the proportion of part-time workers was not due to subcontracting by large export firms to small enterprises or household workers.
} 
of labour income. Furthermore, in Guatemala and Nicaragua there was an increase in the wage gap between men and women, which favoured an increase in inequality (in Guatemala) or offset part of the reduction in such inequality (in Nicaragua). In Costa Rica, El Salvador and Honduras, the wage gap between women and men remained generally unchanged between 1990 and 1999 .

During the period in question, the wage gap between workers in large and small enterprises was narrowed in Guatemala and Nicaragua, did not change in Costa Rica, and widened in Honduras and El Salvador. This means that while differences between wages in large and small enterprises was an important source of inequality in Guatemala and Nicaragua at the beginning of the 1990 s, by the end of the decade this was no longer so.

Finally, except in Honduras, wage differences between industries went down in the 1990s, thus helping to reduce inequality. Furthermore, in all the countries of the subregion the changes in the composition of workers in the different industries only had a very slight effect on the changes observed in the distribution of labour income. It has been suggested that trade liberalization will affect wage inequality though its effect on the composition of industrial employment and changes in the wage differentials between industries. ${ }^{18}$ These results suggest that this effect does not go very far towards explaining the changes in Central American labour income inequality in the 1990s.

Furthermore, these results are in keeping with the findings of other studies, ${ }^{19}$ which, using microsimulation methodology, have found that in most of the countries the economic reforms have been accompanied by greater labour income inequality, because of the insufficient creation of modern-sector jobs, which causes an increase in informal sector employment (it increases the dispersion of hours worked) and an increase in the relative wages of the most highly skilled workers (increases the premium for years of education).

\section{V \\ Sources of differences in labour income inequality among the Central American countries}

In this section, we will compare the sources of labour income inequality in Costa Rica with the corresponding sources in the other Central American countries. As Costa Rica has the relatively most equal distribution in the region, this country is a suitable point of reference. Table 9 shows the results of Yun's decomposition of the difference between Costa Rica and the other countries of the subregion in terms of inequality, as measured by the variance of the logarithm of labour income. The first block in the table shows the contribution of each variable to the observed difference, while the other two blocks show the separate contributions of the prices and the distribution of each variable to the difference in the indicator of inequality between Costa Rica and each of the other Central American countries. In this table, a negative value indicates that that variable or phenomenon helps to reduce the inequality in that country compared with
Costa Rica, while a positive value means that that variable or phenomenon helps to increase the inequality in that country compared with Costa Rica.

There are three important elements which explain why earnings are distributed more equitably in Costa Rica than in any other Central American country: education, area of residence, and wage gaps by industry.

\section{Education}

The differences in the level of education among workers cause less inequality in Costa Rica than in the other Central American countries for two reasons. First, education is distributed better in Costa Rica. This may

\footnotetext{
${ }^{18}$ See Autor and Katz (1999), Katz and Murphy (1992), Koujianou and Pavcnik (2001) and Robertson (1999).

${ }^{19}$ Such as Ganuza, Paes de Barros and others (2001).
} 
TABLE 9

Central America: Yun's decomposition of the differences in labour income inequality compared with Costa Rica, 1999

(For employed persons aged 15 or more with known income and hours worked)

\begin{tabular}{lcccc}
\hline Variables & El Salvador & Guatemala & Honduras & Nicaragua \\
& 1999 & 1998 & 1999 & 1998
\end{tabular}

Contribution of each variable to

the differences in Var Ln $y$

Difference in the variance of the logarithm of labour income

$\begin{array}{rrrr}\mathbf{0 . 0 1} & \mathbf{0 . 6 6} & \mathbf{0 . 4 3} & \mathbf{0 . 2 7} \\ -\mathbf{0 . 0 1} & \mathbf{0 . 2 5} & \mathbf{0 . 1 5} & -\mathbf{0 . 0 5} \\ 0.04 & 0.13 & 0.10 & 0.04 \\ -0.01 & 0.05 & 0.02 & -0.01 \\ 0.02 & 0.04 & 0.06 & 0.02 \\ -0.09 & 0.02 & -0.06 & -0.13 \\ 0.00 & -0.01 & -0.01 & -0.02 \\ 0.00 & 0.00 & 0.04 & -0.02 \\ -0.01 & 0.00 & -0.02 & 0.00 \\ 0.04 & 0.01 & 0.02 & 0.07 \\ \mathbf{0 . 0 1} & \mathbf{0 . 4 2} & \mathbf{0 . 2 8} & \mathbf{0 . 3 2}\end{array}$

Explained by the variables used

Education (years)

Sex $($ men $=1)$

Zone (urban $=1$ )

Hours worked (log)

Institutional sector $($ public $=1)$

Size of establishment ( 6 or more $=1$ )

Experience (age-education-6)

Industry (set of binary variables)

Residual

0.42

0.32

Contribution of changes in the

coefficients of each variable

Total price effect

Education (years)

Sex $($ men $=1)$

Zone (urban $=1$ )

Hours worked (log)

Institutional sector $($ public $=1)$

Size of establishment $(6$ or more $=1$ )

Experience (age-education-6)

Industry (set of binary variables)

Contribution of changes in the

coefficients of each variable

Total distribution effect

Education (years)

Sex $($ men $=1)$

Zone $($ urban $=1)$

Hours worked $(\log )$

Institutional sector $($ public $=1)$

Size of establishment $(6$ or more $=1)$

Experience (age-education-6)

Industry (set of binary variables)

$\begin{array}{rrrr}\mathbf{0 . 0 0} & \mathbf{0 . 2 2} & \mathbf{0 . 1 8} & \mathbf{- 0 . 0 1} \\ -0.02 & 0.10 & 0.08 & 0.01 \\ 0.00 & 0.04 & 0.02 & 0.00 \\ 0.02 & 0.04 & 0.06 & 0.02 \\ -0.03 & 0.01 & -0.04 & -0.09 \\ 0.02 & 0.00 & 0.00 & -0.02 \\ 0.00 & 0.01 & 0.05 & -0.01 \\ 0.01 & 0.02 & -0.01 & 0.01 \\ 0.02 & 0.02 & 0.02 & 0.07\end{array}$

$\begin{array}{rrrr}\mathbf{0 . 0 0} & \mathbf{0 . 0 3} & \mathbf{0 . 0 0} & \mathbf{- 0 . 0 4} \\ 0.07 & 0.04 & 0.03 & 0.03 \\ 0.00 & 0.01 & 0.00 & -0.01 \\ 0.00 & 0.00 & 0.00 & 0.00 \\ -0.05 & 0.01 & -0.01 & -0.04 \\ 0.00 & -0.01 & 0.00 & 0.00 \\ 0.00 & -0.01 & 0.00 & -0.01 \\ -0.02 & -0.01 & -0.01 & -0.01 \\ -0.01 & 0.00 & 0.00 & 0.00\end{array}$

Source: Calculated by the authors on the basis of household surveys of the respective countries and years.

be seen from the distribution effect of the education variable (table 9), and can be corroborated from the values of the standard deviation of that variable given in Appendix A, where the basic statistics of the earnings equations are summarized.

This result is due to the fact that the proportion of workers with very little education is higher in the other Central American countries than in Costa Rica. For example, the percentage of workers who have not completed their primary education is $20 \%$ in Costa Rica, $40 \%$ in El Salvador, $47 \%$ in Honduras, $48 \%$ in Nicaragua and $61 \%$ in Guatemala. As regards higher education, $16 \%$ of Costa Rican workers in the sample have some degree of university education, compared with $12 \%$ in El Salvador, $8 \%$ in Nicaragua and $5 \%$ in Honduras and Guatemala.

Another reason why education is a differentiating factor in labour income distribution between Costa Rica and the rest of the subregion has to do with returns to education (the "price" of education or the effect of an extra year of education on earnings). This effect is lower in Costa Rica than in any of the other countries of the subregion except El Salvador (table 9 and Appendix A) but is highest in the countries with the 
lowest average educational levels (Guatemala and Honduras). In El Salvador, the price effect of education reduces the level of inequality compared with Costa Rica, but this is more than offset by the more unequal distribution of education, so that the overall effect of education in El Salvador is that that country is more unequal in that respect than Costa Rica.

\section{Area of residence}

Rural or urban residence is also a contributory factor in the greater inequality of the rest of the Central American countries, compared with Costa Rica, because in those countries the wage premium received by urban workers is higher than that in Costa Rica. The measured differences in the proportion of urban workers (distribution effect) between countries do not play any part in the differences in inequality between Costa Rica and the other countries, although the proportion of workers living in urban areas is lower in Costa Rica. This suggests that there are elements in the internal production structure of the areas which could explain this result. We will return to this aspect later.

\section{Wage gaps by industry}

The third element which helps to explain the greater inequality of the rest of the Central American countries compared with Costa Rica is the set of binary variables which reflect wage differences between different industrial branches. The inequality due to wage gaps between industries is smaller in Costa Rica than in the rest of the subregion. The differences in inter-industry wage gaps are due mainly to the wage differences between agriculture and the other branches of industrial activity, which suggests that in the analysis and measurement of the effect of inter-industry wage gaps on differences in inequality, account should be taken of the interaction between inter-industry wage gaps and area of residence. Unfortunately, Fields' decomposition does not allow the interactions between variables to be measured adequately. Consequently, in order to examine those interactions, including that of enterprise size, we will directly analyze the coefficients of the earnings equations. ${ }^{20}$

\footnotetext{
${ }^{20}$ The combined contribution of wage gaps due to area of residence, enterprise size and branch of industry to the differences in inequality between Costa Rica and the rest of the Central American countries
}

Table 10 shows these coefficients, as well as the percentage of workers in each category. Eight categories have been defined in which area of residence, enterprise size and branch of industry interact: i) workers on small farms (including employees, managers or owners, and self-employed workers); ii); iii) managers or owners of large farms; iv) workers (including employees, managers or owners, and self-employed workers) in small non-agricultural rural enterprises; v) employees of large non-agricultural rural enterprises; vi) managers or owners of large nonagricultural rural enterprises; vii) workers (including employees, managers or owners, and self-employed workers) in small urban enterprises, and viii) workers in large urban enterprises.

The coefficients of the binary variables shown (table 10) come from an earnings equation which also includes the variables for education, sex, log of hours worked, sector and experience. The category of workers in large urban enterprises is omitted. Thus, the coefficients can be interpreted as the percentage difference between the earnings of the workers in each category and that of workers in large urban enterprises. As may be seen from table 10, in all the countries of the subregion employees of large non-agricultural rural enterprises earn less than workers in large urban enterprises but more than any other type of worker in rural areas. Likewise, employees on large farms earn less than employees of large non-agricultural rural enterprises, but more than workers on small farms. Except in Nicaragua, employees on large farms earn more than employees of small non-agricultural rural enterprises. Finally, workers on small farms (employees and owners) earn less than any other group.

In all the Central American countries, except Honduras, the owners of large rural enterprises, whether agricultural or non-agricultural, earn more than the workers in large urban enterprises. The proportion of owners in the total number of workers is small, however, so that it is unlikely that they have much influence on the global differences between urban and rural earnings. In all the countries, the proportion of rural workers in non-agricultural activities is high, and in Costa Rica and El Salvador it exceeds the proportion of rural workers engaged in agricultural activities.

The results presented in table 10 enable us to understand why the urban-rural wage gap is narrower

is greater than the effect of wage gaps due to education in all the countries except one. 
TABLE 10

Central America: Estimate of effects of interactions between zone, size and industry on labour income inequality, by countries, at the end of the 1990s

(For employed persons aged 15 or more with known income and hours worked)

\begin{tabular}{|c|c|c|c|c|c|}
\hline Variables & $\begin{array}{c}\text { Costa Rica } \\
1999\end{array}$ & $\begin{array}{c}\text { El Salvador } \\
1999\end{array}$ & $\begin{array}{c}\text { Guatemala } \\
1998\end{array}$ & $\begin{array}{c}\text { Honduras } \\
1999\end{array}$ & $\begin{array}{c}\text { Nicaragua } \\
1998\end{array}$ \\
\hline \multicolumn{6}{|l|}{ Coefficients of different types of workers ${ }^{a}$} \\
\hline Workers on small farms & -0.51 & -0.59 & -0.74 & -0.95 & -0.88 \\
\hline Employees on large farms & -0.15 & -0.50 & -0.49 & -0.38 & -0.44 \\
\hline Owners of large farms & 0.22 & 0.91 & 2.28 & -0.87 & 0.39 \\
\hline Employees of small non-agricultural rural enterprises & -0.31 & -0.46 & -0.56 & -0.68 & -0.26 \\
\hline Employees of large non-agricultural rural enterprises & -0.05 & -0.16 & -0.30 & -0.17 & -0.11 \\
\hline Owners of large non-agricultural rural enterprises & 0.34 & 1.16 & 1.19 & 0.88 & \\
\hline Workers in small urban enterprises & -0.24 & -0.27 & -0.31 & -0.34 & -0.16 \\
\hline \multicolumn{6}{|l|}{ Percentage of workers in each category } \\
\hline All workers & 100.0 & 100.0 & 100.0 & 100.0 & 100.0 \\
\hline Workers in agricultural activities & 17.1 & 9.8 & 28.6 & 25.6 & 21.6 \\
\hline Workers on small farms & 10.1 & 3.9 & 16.7 & 21.9 & 14.3 \\
\hline Employees on large farms & 6.8 & 5.9 & 11.7 & 3.6 & 7.0 \\
\hline Owners of large farms & 0.1 & 0.0 & 0.2 & 0.2 & 0.4 \\
\hline Rural workers in non-agricultural activities & 33.9 & 21.3 & 23.4 & 22.3 & 16.9 \\
\hline Employees of small non-agricultural rural enterprises & 17.8 & 13.1 & 18.2 & 15.6 & 11.3 \\
\hline Employees of large non-agricultural rural enterprises & 15.8 & 7.8 & 5.1 & 6.7 & 5.6 \\
\hline Owners of large non-agricultural rural enterprises & 0.3 & 0.4 & 0.1 & 0.0 & 0.0 \\
\hline Workers in urban enterprises & 49.0 & 68.9 & 48.0 & 52.1 & 61.5 \\
\hline Workers in small urban enterprises & 21.1 & 32.5 & 30.4 & 26.8 & 34.8 \\
\hline Workers in large urban enterprises & 27.9 & 36.5 & 17.6 & 25.3 & 26.7 \\
\hline
\end{tabular}

Source: Calculated by the authors on the basis of household surveys of the respective countries and years.

a Percentage difference between earnings of each type of worker and that of workers in large urban enterprises.

in Costa Rica than in the other countries of the subregion. ${ }^{21}$ First, the wage gap between workers in large non-agricultural rural enterprises and large urban enterprises is smaller in Costa Rica than in any other country. Second, the proportion of workers in large non-agricultural rural enterprises, which form the bestpaid rural sector, is higher in Costa Rica than in any other Central American country. Third, the wage gap between workers in large urban enterprises and those in agricultural enterprises, whether large or small, is narrower in Costa Rica than in any other country of the subregion. Fourth, the proportion of workers on small farms is lower in Costa Rica than in the rest of Central America.

\footnotetext{
${ }^{21}$ In Guatemala it was possible to identify whether workers belong to an indigenous group. Although labour discrimination against indigenous persons did help to increase inequality in both 1989 and 1998, this discrimination does not explain the wage gaps between urban and rural areas. Adding a variable which indicates if a worker is indigenous or not does not reduce the contribution to inequality of area of residence, enterprise size or industrial branch.
}

It has been noted that El Salvador belongs to the second block, with a level of inequality which is greater than that of Costa Rica, but less than that of Guatemala, Honduras and Nicaragua. Why do the latter three countries display the greatest inequalities in labour income distribution? This is largely because the residual, or inequality due to unmeasured factors, is much higher in those countries than in Costa Rica and El Salvador (table 9, first block). Thus, for example, the inequality due to the residual (unmeasured factors) is sufficient by itself to explain why the inequality in Nicaragua is more marked than in Costa Rica and El Salvador. The impact of the residual on the earnings equations measures the part of inequality caused by variables which have not been included in the equation. Among the factors not included are the unmeasured differences between the household surveys of the countries. The differences in sample design, in the manner or defining and measuring the variables used - especially labour income-, in the quality of the information collected, in the extent of failure to respond, 
etc., are all aspects which may be reflected in the residual. It is also possible that differences in minimum wage systems may explain some differences due to the residual, if the legal minimum wage has greater coverage and is more effectively applied in Costa Rica and El Salvador than in the other Central American countries. ${ }^{22}$ It is also possible that the inequality associated with indigenous groups, which cannot be measured in most of the countries, is greater in Guatemala, Honduras and Nicaragua.

In the case of Honduras, three phenomena contributed to the high level of inequality. First, the wage premium received by urban workers, or the urban-rural wage gap, is the largest of the entire subregion (Appendix A); its impact is so great that, if inequality were measured only for urban workers (table 2), Honduras would appear to have a degree of inequality similar to that of El Salvador. Second, the wage premium received by workers in larger or formalsector enterprises is likewise higher than in any other Central American country. Much of this result may be due to a earnings gap between wage-earning workers and independent workers (owners or self-employed workers). Once again, if only wage-earning workers are considered (table 2), inequality in Honduras appears similar to that of El Salvador. Lastly, the wage gap (controlling for other measurable characteristics of human capital and the labour market) between men and women is larger in Honduras than in the other countries (Appendix A). This may be interpreted as a rough measure of discrimination against women in the labour market.

The similarly high level of inequality of labour income in Guatemala is likewise explained by three factors. First, the urban-rural wage gap is larger than anywhere else in the subregion except Honduras. Second, the wage gap between men and women is also

\footnotetext{
22 Although only Costa Rica adjusts the legal minimum wage periodically (every six months), these two countries have the highest minimum wages in the subregion.
}

one of the largest, again exceeded only by that of Honduras (Appendix). Lastly, the inequality associated with the number of hours worked is similar to that of Costa Rica and is more marked than in any other country (table 3). This is because Guatemala and Costa Rica have the highest coefficient of the variable for the $\log$ of hours worked (Appendix); in other words, workers' earnings increases more rapidly if they work overtime than in the rest of the Central American countries, and the inequality due to the distribution of hours worked is also very high (table 9).

Finally, two additional aspects are worthy of emphasis. First, the conclusions of this study are limited to those that can be justified on the basis of the information from household surveys, but it is possible that there may be other variables that are important causes of the differences in inequality between countries. In this respect, it was noted earlier that the wage gap between indigenous and non-indigenous workers is an important source of inequality in Guatemala, but no comparison can be made with the other Central American countries. In a recent World Bank study (Ferrari, Perry and others, 2004), evidence is presented that the differences between countries in respect of the wage gap between indigenous and nonindigenous workers explains a significant part of the overall differences in inequality between one country and another. Second, the information used and analyses made are limited to the 1990s, so that it is not possible to draw conclusions about the historical reasons for the patterns observed. For example, it has been found that the lower relative inequality in Costa Rica is due to a more equitable distribution of education and a smaller wage gap between urban and rural areas, also associated with greater and more equitable investment in infrastructure and in the provision of social services. The World Bank study referred to above concurs with these reasons and links them with historical roots of the socio-economic structure and the political transition of the late $19^{\text {th }}$ century. Opposite historical reasons, it is said, explain the higher levels of inequality in Guatemala. 


\section{VI}

\section{Policy conclusions}

In the 1990s, the changes in labour income inequality in the Central American countries were not all in the same direction; whether inequality increased or decreased depends on the country considered and the indicator of inequality used. Only Costa Rica and Guatemala show a clear deterioration in labour income inequality. Beneath these overall changes, however, there are a number of phenomena which are common to the labour markets in all the countries. The phenomenon which has had the most important adverse effect on labour income inequality is the decline in the percentage of workers with a full working day in each country and the concomitant increase in the percentages working part-time or overtime. This change increased the dispersion of the number of hours worked, thus accentuating labour income inequality. The decline in the percentage of workers with a full working day reflects the reduction in public sector employment in all the countries of the subregion. The increase in part-time workers, for its part, reflects the growing proportion of women in the labour force and the increasing importance of small private enterprises (the informal sector) as a source of employment, while the increase in workers with overtime is associated with the larger enterprises and their efforts to improve their productivity and profitability.

In the present study we also investigated the differences between the Central American countries, and in particular, why Costa Rica has a lower level of inequality than the others. One important reason for this phenomenon is that education is more equitable distributed in Costa Rica. Almeida dos Reas and Paes de Barros (1991), who presented a model on the expansion of education and inequality, concluded that the expansion of education reduces inequality if it takes place in educational levels in which workers earn less than the average income. If it is concentrated in educational levels at which workers earn more than the average wage, however, such as university education, such expansion helps to increase inequality. ${ }^{23}$ This

23 On the other hand, the expansion of education in levels of education higher than the average (i.e., which increases the proportion of workers earning more than the average wage and lowers the proportion of workers earning less than that amount) suggests that the policies aimed at the universalization of primary education applied in Costa Rica in the 1960s and 1970s were an important cause of the different levels of inequality found. Those policies lowered the proportion of workers without education or with only incomplete primary education and increased the proportion with full primary education. Likewise, in Costa Rica and El Salvador the return to education (the price of education) is lower than in Guatemala, Honduras and Nicaragua, where educational levels are very low. This suggests that the greater relative supply of workers of higher educational level in Costa Rica and El Salvador helps to reduce the relative price of education and, hence, improve income distribution.

It has also been found that wage differences between urban and rural areas are smaller in Costa Rica because in that country the workers in large nonagricultural rural enterprises (presumably of high productivity) earn more and form a larger proportion of rural workers than in the rest of Central America. Such results are consistent with the results and policy recommendations contained in López and Valdés (2000). In that study, which summarizes studies on rural poverty in various Latin American countries, including El Salvador, Guatemala and Honduras, evidence is presented that large rural enterprises pay more than other rural jobs, and furthermore, rural workers in Latin America are less dependent on agriculture than in almost any other place in the developing world. It is also suggested that in order to reduce rural poverty, the major part of public resources should be devoted to improving earnings and work opportunities in non-agricultural jobs in rural areas, and proof is presented that there is a correlation between the proportion of non-agricultural rural jobs with high productivity, on the one hand, and higher average levels of education and better rural infrastructure (such as roads, electricity, telephones, etc.) on the other. This suggests that Costa Rica's public policies of providing

can either increase or decrease inequality. This type of expansion will increase inequality if there are only a few workers of high educational level, but it will reduce inequality if there are many workers of that level. This is an example of the famous Kuznets Curve. 
even the remotest rural communities with electricity, telephones, education, health and transport infrastructure (all closely related with high-productivity non-agricultural rural activities), is also an important reason for the differences in inequality between Costa
Rica and the rest of the subregion, and gives an idea of the kind of public policies that should be adopted in order to reduce poverty and inequality.

(Original: Spanish)

APPENDIX

Central America: Basic statistics of the earnings equations, by countries, at the end of the 1990s

(For employed persons aged 15 or more with known income and hours worked)

\begin{tabular}{|c|c|c|c|c|c|c|c|c|c|c|}
\hline \multirow[t]{2}{*}{ Variables } & \multicolumn{2}{|c|}{ Costa Rica } & \multicolumn{2}{|c|}{ El Salvador } & \multicolumn{2}{|c|}{ Guatemala } & \multicolumn{2}{|c|}{ Honduras } & \multicolumn{2}{|c|}{ Nicaragua } \\
\hline & 1990 & 1999 & 1995 & 1999 & 1989 & 1998 & 1990 & 1999 & 1993 & 1998 \\
\hline \multicolumn{11}{|l|}{$\begin{array}{l}\text { Coefficients of the } \\
\text { earnings equations }\end{array}$} \\
\hline Education (years) & 0.087 & 0.089 & 0.064 & 0.081 & 0.093 & 0.112 & 0.116 & 0.106 & 0.087 & 0.094 \\
\hline $\operatorname{Sex}(\operatorname{men}=1)$ & 0.278 & 0.270 & 0.307 & 0.241 & 0.313 & 0.464 & 0.479 & 0.469 & 0.136 & 0.323 \\
\hline Zone $($ urban $=1)$ & 0.087 & 0.060 & 0.255 & 0.169 & 0.156 & 0.243 & 0.257 & 0.313 & 0.312 & 0.156 \\
\hline Hours worked (log) & 0.573 & 0.571 & 0.421 & 0.423 & 0.488 & 0.562 & 0.353 & 0.415 & 0.244 & 0.172 \\
\hline Institutional sector $($ public $=1)$ & 0.233 & 0.211 & 0.288 & 0.439 & 0.166 & 0.085 & 0.237 & 0.175 & -0.102 & -0.164 \\
\hline Size of establishment $(6$ or more $=1)$ & 0.273 & 0.270 & 0.252 & 0.283 & 0.470 & 0.325 & 0.385 & 0.426 & 0.440 & 0.272 \\
\hline Experience (age-education-6) & 0.033 & 0.027 & 0.030 & 0.037 & 0.033 & 0.054 & 0.046 & 0.039 & 0.039 & 0.041 \\
\hline Experience squared & -0.0004 & -0.0003 & -0.0004 & -0.0005 & -0.0004 & -0.0007 & -0.0005 & -0.0004 & -0.0005 & -0.0005 \\
\hline $\begin{array}{l}\text { Industry (set of binary } \\
\text { variables) }\end{array}$ & sig & sig & sig & sig & sig & $\operatorname{sig}$ & sig & sig & sig & sig \\
\hline $\mathrm{R}^{2}$ & 0.486 & 0.503 & 0.460 & 0.494 & 0.441 & 0.443 & 0.450 & 0.450 & 0.387 & 0.324 \\
\hline Number of observations & 9.704 & 13.152 & 10.365 & 19.824 & 12.747 & 11.615 & 12.293 & 10.778 & 4.806 & 5.978 \\
\hline \multicolumn{11}{|l|}{$\begin{array}{l}\text { Standard deviation of the } \\
\text { independent variables }\end{array}$} \\
\hline Education (years) & 4.06 & 4.06 & 5.14 & 5.03 & 4.33 & 4.61 & 4.21 & 4.47 & 4.64 & 4.66 \\
\hline $\operatorname{Sex}(\operatorname{men}=1)$ & 0.45 & 0.47 & 0.49 & 0.50 & 0.44 & 0.48 & 0.46 & 0.48 & 0.49 & 0.48 \\
\hline Zone $($ urban $=1)$ & 0.50 & 0.50 & 0.47 & 0.46 & 0.50 & 0.50 & 0.50 & 0.50 & 0.48 & 0.49 \\
\hline Hours worked (log) & 0.46 & 0.56 & 0.41 & 0.47 & 0.35 & 0.58 & 0.47 & 0.56 & 0.58 & 0.55 \\
\hline Institutional sector $($ public $=1)$ & 0.39 & 0.34 & 0.32 & 0.31 & 0.28 & 0.23 & 0.30 & 0.27 & 0.39 & 0.32 \\
\hline Size of establishment $(6$ or more $=1)$ & 0.50 & 0.50 & 0.50 & 0.50 & 0.49 & 0.48 & 0.48 & 0.48 & 0.49 & 0.49 \\
\hline Experience (age-education-6) & 14.36 & 14.12 & 15.68 & 16.00 & 16.25 & 17.20 & 16.23 & 16.26 & 15.15 & 15.52 \\
\hline \multicolumn{11}{|l|}{$\begin{array}{l}\text { Average value of the } \\
\text { independent variables }\end{array}$} \\
\hline Education (years) & 7.33 & 7.81 & 5.88 & 7.01 & 3.83 & 4.55 & 4.48 & 5.45 & 5.47 & 5.81 \\
\hline $\operatorname{Sex}(\operatorname{men}=1)$ & 0.71 & 0.68 & 0.61 & 0.56 & 0.74 & 0.64 & 0.70 & 0.63 & 0.62 & 0.64 \\
\hline Zone $($ urban $=1)$ & 0.46 & 0.49 & 0.67 & 0.69 & 0.44 & 0.48 & 0.48 & 0.52 & 0.64 & 0.61 \\
\hline Hours worked (log) & 3.76 & 3.74 & 3.77 & 3.72 & 3.80 & 3.65 & 3.77 & 3.74 & 3.74 & 3.80 \\
\hline Institutional sector $($ public $=1$ ) & 0.18 & 0.13 & 0.11 & 0.11 & 0.09 & 0.06 & 0.10 & 0.08 & 0.19 & 0.11 \\
\hline Size of establishment $(6$ or more $=1)$ & 0.57 & 0.51 & 0.53 & 0.50 & 0.39 & 0.35 & 0.35 & 0.36 & 0.40 & 0.40 \\
\hline Experience (age-education-6) & 20.49 & 22.86 & 24.10 & 23.27 & 26.57 & 26.80 & 25.80 & 24.57 & 24.29 & 23.91 \\
\hline
\end{tabular}

Source: Calculated by the authors on the basis of household surveys of the respective countries and years. 
Autor, D. and L. Katz (1999): Changes in the wage structure and earnings inequality, in O. Ashenfelter and D. Card (eds.), Handbook of Labor Economics, vol. 3A, New York, NorthHolland.

Almeida dos Reas, J.G. and R. Paes de Barros (1991): Wage inequality and the distribution of education: a study of the evolution of regional differences in inequality in metropolitan Brazil, Journal of Development Economics, vol. 36, No. 1, Amsterdam, Elsevier Science, July.

Contreras, D. (2003): Explaining wage inequality in Chile, Journal of Income Distribution, vol. 11, No. 1-2, Amsterdam, Elsevier Science.

De Ferrari, D., G. Perry and others (2004): Inequality in Latin America and the Caribbean: Breaking with History, Washington, D.C., World Bank.

ECLAC (Economic Commission for Latin America and the Caribbean) (2001): Social Panorama of Latin America, 20002001, LC/G.2138-P, Santiago, Chile, September. United Nations publication, Sales No. E.01.II.G.141.

(2002): Social Panorama of Latin America, 2001-2002, LC/ G.2183-P, Santiago, Chile, October. United Nations publication, Sales No. E.02.II.G.65.

(2003): Statistical Yearbook for Latin America and the Caribbean, 2002, LC/G.2190-P, Santiago, Chile. United Nations publication, Sales No. E/S.03.II.G.1.

Fields, G.S. (2003): Accounting for income inequality and its change: a new method, with application to the distribution of earnings in the United States, in S. Polachek (ed.), Research in Labor Economics, vol. 22, Amsterdam, Elsevier Science.

Fields, G.S. and I. Gyeongjoon (2000): Falling labor income inequality in Korea's economic growth: patterns and underlying causes, Review of Income and Wealth, vol. 46, No. 1, New York, New York University, June.

Ganuza, E., R. Paes de Barros and others (eds.) (2001): Liberalización, desigualdad y pobreza: América Latina y el Caribe en los 90, Buenos Aires, EUDEBA.

Gindling, T.H. and J.D. Trejos (2004): Accounting for changing earnings inequality in Costa Rica, 1980-1999, Journal of Development Studies, Amsterdam, Elsevier Science, forthcoming.

Juhn, C., K. Murphy and B. Pierce (1993): Wage inequality and the rise in returns to skill, Journal of Political Economy, vol. 101, No. 3, Chicago, University of Chicago Press.

Katz, L. and K. Murphy (1992): Changes in relative wages, 1963-
1987: supply and demand factors, Quarterly Journal of Economics, vol. 107, Cambridge, Massachusetts, Harvard University.

Koujianou Goldberg, P. and N. Pavcnik (2001): Trade, Wages, and the Political Economy of Trade Protection: Evidence from the Colombian Trade Reforms, Hanover, NH, Dartmouth College, November, unpublished.

López, R. and A. Valdés (2000): Fighting rural poverty in Latin America: new evidence of the effects of education, demographics, and access to land, Economic Development and Cultural Change, vol. 49, No. 1, Chicago, University of Chicago Press, October.

Lora, E. (2001): Structural Reforms in Latin America: What Has Been Reformed and How to Measure It, Research Department Working Paper, No. 466, Washington, D.C., Inter-American Development Bank (IDB), December.

Morley, S., R. Machado and S. Pettinato (1999): Indexes of Structural Reform in Latin America, "Reformas económicas" series, No. 12, LC/L.1166, Santiago, Chile, Economic Commission for Latin America and the Caribbean (ECLAC).

Robertson, R. (1999): Inter-Industry Wage Differentials across Time, Borders, and Trade Regimes: Evidence from the U.S. and Mexico, St. Paul, Macalester College, unpublished.

Shorrocks, A. (1982): Inequality decomposition by factor components, Econometrica, vol. 50, No. 1, Evanston, Illinois, The Econometric Society, January.

Székely, M. and M. Hilgert (1999a): The 1990s in Latin America: Another Decade of Persistent Inequality, Research Department Working Paper, No. 410, Washington, D.C., Inter-American Development Bank (IDB), December.

(1999b): What's Behind the Inequality We Measure: An Investigation Using Latin American Data for the 1990s, Bank Research Department, Washington, D.C., Inter-American Development Bank (IDB), December.

Trejos, J.D. (2002): El trabajo decente y el sector informal en los países del istmo centroamericano, document No. 158, San Jose, International Labour Organization, Office for Central America, Panama and the Dominican Republic.

UNDP (United Nations Development Programme) (2002): Human Development Report, 2002: Deepening Democracy in a Fragmented World, New York, Oxford University Press.

Yun, M. (2002): Earnings Inequality in the USA, 1961-1999: Comparing Inequality Using Earnings Equations, Tulane University, unpublished. 